\title{
Sprawozdanie
}

\section{Konferencja Naukowa nt. „Konstytucjonalizm w państwach anglosaskich”, Kraków 24-25 maja 2012 r.}

W dniach 24-25 maja 2012 r. na Uniwersytecie Jagiellońskim w Krakowie odbyła się konferencja „Konstytucjonalizm w państwach anglosaskich” zorganizowana przez Katedrę Konstytucjonalizmu i Ustrojów Państwowych Instytutu Nauk Politycznych i Stosunków Międzynarodowych UJ. W konferencji wzięli udział prawnicy i politolodzy zajmujący się różnorodnymi aspektami ustrojowymi państw anglosaskich - Zjednoczonego Królestwa Wielkiej Brytanii i Irlandii Północnej, Stanów Zjednoczonych Ameryki, Kanady, Związku Australijskiego i Nowej Zelandii. Uczestnicy konferencji reprezentowali jednostki naukowe działające w ramach różnych ośrodków akademickich: Uniwersytetu Jagiellońskiego, Uniwersytetu Warszawskiego, Uniwersytetu Śląskiego w Katowicach, Chrześcijańskiej Akademii Teologicznej w Warszawie oraz Wyższej Szkoły Europejskiej im. ks. Józefa Tischnera w Krakowie.

Uczestników powitał prof. dr hab. Andrzej Zięba, kierownik Katedry Konstytucjonalizmu i Ustrojów Państwowych UJ. Otwarcia konferencji dokonali prof. dr hab. Andrzej Mania, prorektor UJ ds. dydaktyki oraz prof. dr hab. Bogdan Szlachta, dziekan Wydziału Studiów Międzynarodowych i Politycznych UJ.

W pierwszym dniu konferencji obrady prowadzone były w ramach trzech paneli dyskusyjnych. Odbyły się one w sali im. M. Bobrzyńskiego Collegium Maius. Panelowi pierwszemu przewodniczył prof. dr hab. Marian Grzybowski. Obrady rozpoczęły się od referatu prof. dr. hab. Andrzeja Zięby pt. Struktura i źródła konstytucji materialnej Zjednoczonego Królestwa. Wystąpienie prof. dr. hab. Wawrzyńca Konarskiego dotyczyło historii ustrojowej Republiki Irlandii Rodowód i ewolucja konstytucjonalizmu irlandzkiego. Elementom brytyjskiego prawa wyznaniowego poświęcony został referat dr. hab. Tadeusza J. Zielińskiego pt. Prawa i powinności monarchy brytyjskiego wobec religii urzędowej i Kościołów państwowych. Przedmiotem wystąpienia 
mgr Marty Przygody była natomiast problematyka praw człowieka w referacie Materia praw człowieka w brytyjskich projektach konstytucji formalnej.

Obrady w ramach panelu drugiego prowadził prof. dr hab. Wawrzyniec Konarski. Referat pt. Dynamiczna równowaga czy antagonistyczna wspótpraca? Współczesny podział władzy $w$ amerykańskim konstytucjonalizmie przedstawił prof. dr hab. Ryszard M. Małajny. Problematyce amerykańskiej były też poświęcone trzy kolejne wystąpienia. Dr Paweł Laidler wygłosił referat pt. Proceduralna i materialna właściwość prawa: XIV poprawka i jej rola w rozwoju amerykańskiego konstytucjonalizmu. Dr Sebastian Kubas wystąpił z referatem pt. Ingerencja amerykańskiego sadu konstytucyjnego w proces wyborczy. Uwagi na tle orzeczenia Citizens United v. Federal Election Commission (2010). Dr Krzysztof Zwierzchowski zajął się natomiast instytucją referendum stanowego w procesie stanowienia konstytucji stanowych w USA.

W obradach prowadzonych w trakcie panelu trzeciego, którego moderatorem był prof. dr. hab. Ryszard M. Małajny, obecne były wątki historyczne. Dr Grzegorz M. Kowalski zaprezentował referat pt. Konstytucjonalizm anglosaski w polskiej literaturze prawniczej XVIII w., z kolei wystąpienie dr. Bartosza Włodarskiego dotyczyło Szkoły Nauk Politycznych UJ - jednostki naukowo-dydaktycznej, której działalność przypadła głównie na okres dwudziestolecia międzywojennego. Miało ono tytuł: Problematyka anglosaska $w$ wykładach Szkoły Nauk Politycznych UJ. W ramach panelu trzeciego znalazły się ponadto wystąpienia mgr. Mateusza Kolaszyńskiego pt. Status ustrojowy służb specjalnych $w$ brytyjskim porządku państwowym oraz dr. hab. Andrzeja Bryka pt. Sąd Najwyższy Stanów Zjednoczonych Ameryki a wojna kultur.

W drugim dniu konferencji obrady toczyły się w ramach czterech paneli dyskusyjnych. Odbyły się one w sali konferencyjnej Collegium Novum oraz w Sali Posiedzeń Instytutu Nauk Politycznych i Stosunków Międzynarodowych UJ. Obrady panelu czwartego prowadził prof. dr hab. Andrzej Zięba. Pierwszym prelegentem był dr hab. Jan Lencznarowicz, którego wystąpienie dotyczyło źródeł konstytucjonalizmu australijskiego (tytuł: Geneza konstytucji Związku Australijskiego). Dr Aleksander Dańda wygłosił referat pt. Ewolucja pozycji ustrojowej generalnego gubernatora $w$ dominiach brytyjskich. Mgr Justyna Eska przedstawiła niektóre problemy konstytucjonalizmu nowozelandzkiego w referacie poświęconym elementom modelu westminsterskiego w porządku konstytucyjnym Nowej Zelandii. Natomiast mgr 
Dorota Rajca zajęła się niektórymi aspektami australijskiego porządku terytorialnego, przedstawiając referat: Status ustrojowy terytoriów w Związku Australijskim.

Obradom panelu piątego przewodniczyła dr hab. Marta Kijewska-Trembecka. W wystąpieniach dominowała problematyka konstytucjonalizmu brytyjskiego. Dr hab. Piotr Mikuli przedstawił referat pt. Problematyka ratyfikacji $i$ implementacji umowy międzynarodowej $w$ systemie ustrojowym Zjednoczonego Królestwa. Dr Tomasz Wieciech wystąpił z referatem pt. Wpływ ustawy wyznaczajacej kadencje parlamentu (Fixed-term Parliaments Act, 2011) na brytyjski system rządów. Wystąpienie dr. Janusza Karpa dotyczyło problematyki praw społecznych (Prawa społeczne $w$ doktrynie konstytucjonalizmu anglosaskiego). Z kolei dr Przemysław Biskup zaprezentował referat pt. Doktryna suwerenności Parlamentu a europejskie procedury decyzyjne w świetle European Union Act 2011.

Obrady panelu siódmego, moderowanego przez dr. Grzegorza M. Kowalskiego, otworzył dr Krzysztof Winkler wystąpieniem pt. Relacje pomiędzy państwami Wspólnoty Narodów zgodnie z postanowieniami Statutu Westminsterskiego. Dr Tomasz Soroka przedstawił referat pt. Quebecka lekcja dla Szkocji. Prawne podstawy organizacji referendów niepodległościowych w Szkocji i w Quebecu - analiza porównawcza. Przedmiotem wystąpienia mgr. Wojciecha Golca było tzw. prawo wojenne, a konkretnie Instytucja martial law w historii ustroju Wielkiej Brytanii. Z kolei referat mgr Elżbiety Sadowskiej pt. Obraz władzy lokalnej w brytyjskiej nauce prawa na przełomie $X I X i X X w$. dotyczył problematyki samorządowej.

Obrady ostatniego panelu prowadził dr hab. Piotr Mikuli. Rozpoczęły się one referatem dr. Łukasza Jakubiaka pt. Rozwój instytucji demokracji bezpośredniej w państwach anglosaskich. Dr hab. Marta Kijewska-Trembecka zaprezentowała referat pt. Kanadyjska konstytucja 1982 - trzy dekady bez sukcesu ratyfikacyjnego. W wystąpieniu pt. Dewolucja w Szkocji i Walii aktualny stan rozwiązań i perspektywy rozwoju dr Małgorzata Kaczorowska zajęła się niektórymi aspektami porządku terytorialnego Zjednoczonego Królestwa. Problematyce tej poświęcony był także referat dr Beaty Kosowskiej-Gąstoł pt. Wpływ dewolucji na brytyjskie partie polityczne ze szczególnym uwzględnieniem zmian zachodzacych w Szkocji.

W konkluzji warto podkreślić, że konferencja „Konstytucjonalizm w państwach anglosaskich" stworzyła okazję do wymiany poglądów naukowców 
koncentrujących się w prowadzonych badaniach na różnorodnych komponentach systemów politycznych państw anglosaskich. Można mieć nadzieję, że uczestnictwo w konferencji przyczyni się do pogłębienia współpracy naukowej i skłoni do podejmowania podobnych przedsięwzięć w przyszłości.

Łukasz Jakubiak (Uniwersytet Jagielloński) 